ISSN: 2277-4998

International Journal of Biology, Pharmacy and Allied Seiences (IJBPAS)

'A Bridge Betuen Caboratory and QRendo'

WwW.iibpas.com

\title{
GREEN MARKETING STRATEGIES -NEW DEVELOPMENTS
}

\section{SAURABH KESWANI*, KKAIWALYA JOSHI, SNEHA DAS AND AMIT MEENA}

Symbiosis Institute of Business Management, Symbiosis International (Deemed University),

Pune, India

*Corresponding Author: E Mail: Punesaurabh.keswani.mba22@associates.sibmpune.edu.in

Received $19^{\text {th }}$ May 2021; Revised $4^{\text {th }}$ June 2021; Accepted $9^{\text {th }}$ July 2021; Available online $25^{\text {th }}$ Sept. 2021

https://doi.org/10.31032/IJBPAS/2021/10.9.1007

\begin{abstract}
Turn the tap off while brushing your teeth. Switch the lights off while walking out of the room. Recycle, reuse and reduce. Make donations and participate in worthy causes. Think of various ways of how you can make daily contributions to lessen the carbon footprints and making this planet a better place to live. Today, it is everyone's responsibility to save the environment and make it sustainable for our coming generations. It is considered as everyone's duty to act in a socially responsible way. And today's consumers are of the view that corporations and business firms are not an exception. CSR is also known as Conscious Capitalism and Corporate Citizenship. Now, the question arises whether consumers actually care about corporate citizenship and are willing to pay extra cost when it comes to actual buying? A study done by 2004 Cone Corporate Citizenship stated that about $90 \%$ of the people favour to switching over to the brands and products that have a good corporate citizenship reputation (2004 Cone Corporate Citizenship Study). Another survey by Nielson on CSR found out that most of the global respondents are willing to pay a premium for the products and services that comes from socially and environmentally responsible company (Nielson Global Survey). This paper examines how Green Marketing is a new tool to CSR. How companies are taking Green Marketing as a Social Initiative. Companies are making strategies that help save the environment and building their image as an eco-friendly company. Is it a strategic CSR? Or Are they really engaged in fulfilling their social responsibility? A take on Strategic CSR of companies by adopting Green Marketing is the main discussion of this paper.
\end{abstract}

Keywords: Green marketing, recycle, reuse and reduce 


\section{INTRODUCTION}

Green Marketing is much more than a just a marketing strategy. A careful and proper analysis is needed to draw a layout for green marketing. Managers should decide how much to invest in environmental activities. They should also decide whether to invest in product itself or in the activities that are environmentally and socially responsible. A decrease in customers, employees and all other stakeholders to increase the competitiveness. And all these things together increase the importance of corporate social responsibility (Mazarr, 1999; Palazzi and Starcher, 2000).

\section{Literature Review}

\section{CORPORATE SOCIAL RESPONSIBILITY}

Investment may bring risk to the image of the company, reduced support by the stakeholders, difficult to recover the losses and eventually the company will die (Wood, 1991). On the other hand, investing more than required will lead to higher costs and eventually lesser competitiveness. And so the corporate world is concerned (Levin, 1993). Today, managers have to deal with so many changes happening in the business environment. Globalisation, competition, changes in technology, changes in demographics, environment, customer preferences, and value system are all the changes that mangers have to deal with (Karna et al., 2001). Companies have to deal with relationships with all- suppliers,
The notion of sustainable development proposed the responsibility of companies as social, economic and environmental (Peattie, 1995). There are many definitions of corporate social responsibility but none is commonly accepted. The definition by UNIDO is, "CSR is a management concept whereby companies integrate social and environmental concerns in their business operations and interactions with their stakeholders" (United Nations Industrial Development Organization). Corporate social responsibility is linked to decision making of the businesses regarding ethics, legal requirements, society and environment (Karna et al., 2001). According to World Business Council for Sustainable Development, CSR can be defined as, "the commitment of business to contribute to sustainable economic development, working with employees, their families, the local community and society at large to improve the quality of life" (WBCSD, 2000). Doing more than economic, technical and legal obligations is what CSR means (Carroll, 1999). Good governance, eco-efficiency, good working conditions for employees, anti-corruption actions, environmental management are among main issues of CSR (UNIDO). Corporate social responsibility not only brings the profit to the organization but also increases the goodwill of the company 
(Seth and Khan, 2015). It also helps the companies to gain the competitive advantage (Simanaviciene, 2009; Dagiliene, 2010). According to Seth and Khan there are four dimensions of CSR in relation with Green Marketing i.e. Economic, Philanthropy, Legal and Ethical (Seth and Khan, 2015). There are certain tools and methods which are required for the successful implementation of CSR which are still in the beginning age (Piercy and Lane, 2009).

Competitive advantage can be gained through environmental performance by adopting a 'Strategic Environmental Management Model' (Porter and van der Linde, 1995). Implementation of green marketing is not just the duty of marketing department but of all the departments of the organization (Seth and Khan, 2015). To augment a firm's CSR, the businesses should incorporate and encourage green marketing (Schubert et al., 2010). Regulatory compliance is one of the main reasons to do green marketing and this is one of the aspects of CSR (Carroll, 1991). According to Ham and Choi, the successful implementation of green marketing strategies may lead to positive results from all the stakeholders of the organization (Ham and Choi, 2012).

\section{Motives of the study}

The following are the motives of this study: 


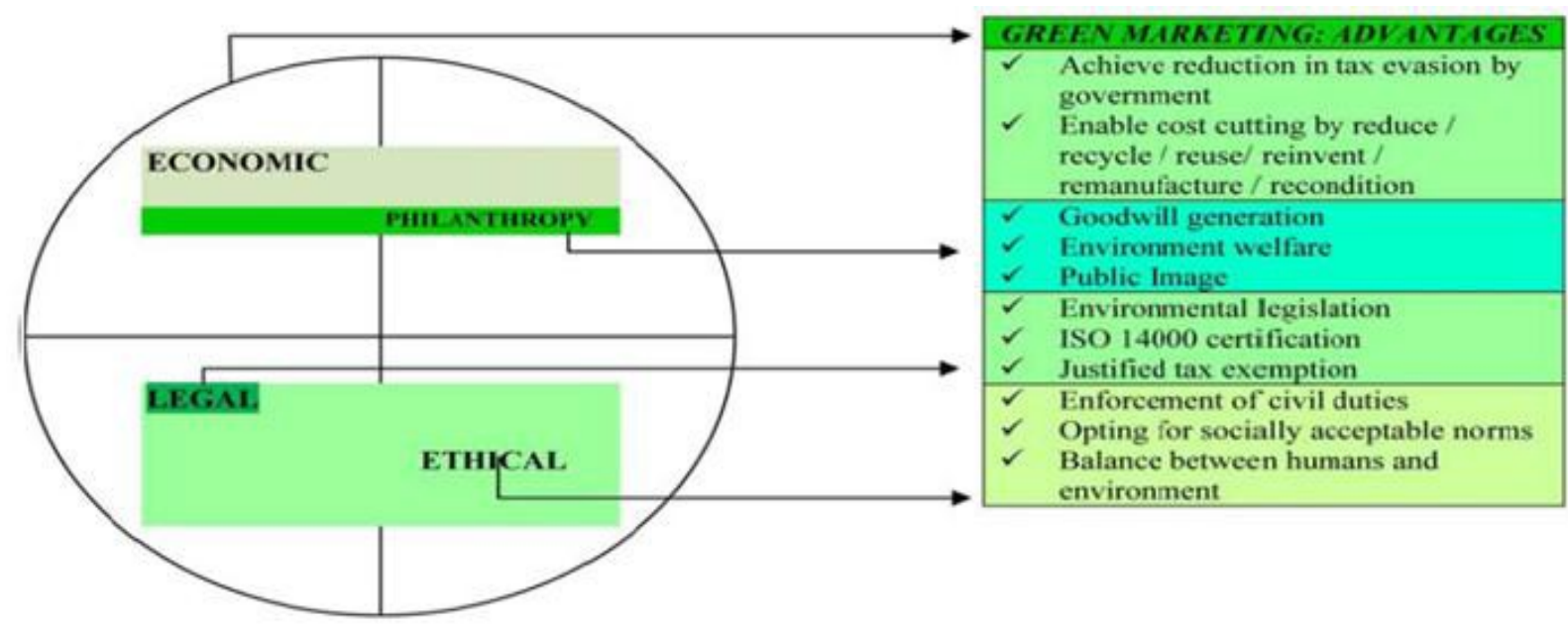

Source: Salil Seth, M. S. Khan, Management Studies and Economic Systems (MSES), 1 (3), 181-188, Winter 2015

\section{Green Marketing}

Figure 1: 4 dimensions of CSR in relation to green marketing
Green marketing is a tool for sustainable development (J. Karna et al., 2001). According to Peattie, green marketing can be defined as, "the holistic management process responsible for identifying, anticipating and satisfying the requirements of customers and society, in a profitable and sustainable way" (Peattie, 1995). In current times, CSR is an inseparable variable of business and a very important issue in management (Alas and Ubius, 2009) and the increasing concern for the environment has made CSR into a very influential idea. During the last few years, because of the grown environmental concern, green marketing and sustainable growth has increased demand among the society (Jhawar et al., 2012; Chen and Chang, 2012; Leonidou et al., 2013).

"Societal Marketing Concept" is the term used by Kotler to describe social and environmental responsibilities (Kotler,
2000). Green marketing is now following a holistic approach and is included in marketing literature (McDonagh and Prothero, 1997). It includes many activities like changes in product, production, packaging, labelling and advertising.

1) To examine how companies are getting benefitted by adopting Green Marketing as a socialinitiative.

2) To analyze the Strategic CSR of the companies.

\section{MATERIALS AND METHODS}

The research is exploratory and descriptive both in nature. The study is based on secondary data. The data is collected from sources like websites, online journals and articles. A deep and close analysis is done of the data to extract the best information from it.

BENEFITS OF ADOPTING GREEN MARKETING AS A SOCIAL INITIATIVE

There are companies which adopt CSR 
strategies as marketing strategy, some as environmental strategy and some use it for both. The companies which adopt CSR strategies for both the reasons gain a competitive advantage (Daria Bosewell, 2012). Organizations need to report CSR activities which should be transparent and accurate.

CSR reports are a part of strategic CSR initiatives which can reap the company the following benefits:

1) Improved reputation and superior brand image

Cone Inc. Did a survey with a title "Millennial Case Study" and found out that if a company is socially responsible and environmentally supportive then $83 \%$ people will believe in the company. $66 \%$ of people will also recommend products and services coming from such company. Doing CSR activities will generate respectable feelings for the company. Customer and media will look towards the constructive effects it has on society (Sofia Ribeiro, 2010).

\section{2) Customer loyalty and profit} increment

Our next generation is fully aware of the threats to the environment i.e. pollution, global warming and extinction of many species. In a survey, 2/3rd of respondents said that while purchasing they consider companies' commitment to society and environment (Cone Inc. Survey). 89\% agreed to switch to the brands that are engaged in some CSR activities.

\section{3) Retain existing employees and attract} newones

A socially responsible company is known to value the employees. A recent poll found out that $80 \%$ of young job seekers look forward to join a company which has a positive effect on the environment and $92 \%$ are more willing to work for a company which is green (MonsterTRAK.com).

4) Increased morale of employees and higherproductivity

Past studies show that employees of companies that feel responsible for social and natural environment also feel motivated with increased productivity (Sofia Ribeiro, 2010).

\section{5) Favourable treatment by government}

The government provide tax incentives and other monetary and non-monetary benefits to the companies that are environmentally and socially responsible. Due to these benefits the start-ups and other companies feel motivated to do CSR activities in relation to green marketing.

\section{6) Reduction in operations costs}

By recycling, reusing and reducing, the companies can achieve reduced operating costs. By simple gestures like switching off lights and computers, less printing, more extended use of electronics the company can reduce the costs and thereby increasing profits. 


\section{Companies involved in csr in relation to green marketing}

\section{1) General Electric}

It's the first corporation to fully embrace Green Marketing movement. GE launched an initiative "Ecomagination" in 2005 to decrease greenhouse gases, produces green products and promotes clean energy. According to Reuter's reports the company will be spending $\$ 10$ billion more on clean energy resources by 2020 as its CSR initiatives.

This initiative by General Electric is considered as a strategic marketing strategy to build up good image which had been struggling for it till 21st century (Wendy Parish, 2015).

\section{2) Starbucks}

Starbucks, a coffee chain which is usually in the list of Fortune's Top 100 companies and is highly successful is absolutely adhered to the practise of "fair-traded coffee". This practise pays an extra dollar to farmers. This in turn motivates the farmers to grow coffee instead of cocoa plant which is used to make cocaine and ruin the society. Starbucks also favours biodiversity and sustainable agriculture. With the help of these practises the company is able to make huge profits because of its increased reputation and goodwill in the market.

\section{3) NDTV}

New Delhi Television in collaboration with
Toyota launched "Greenathon" on 7th of February. It was an event launched to make people aware about environmental issues.

\section{4) Henkel India Ltd.}

Henkel India Ltd. initiated a learning program "Eco-learn" to create environmental awareness and concern for sustainability.

\section{5) Coca-Cola}

Mostly soft drinks companies are not in the consumer's top list of green companies because of the trash in tons it generate. But Coca-Cola came up as a one of the exception with its initiative of the "Plant Bottle". These bottles are made out of $30 \%$ waste plant material of sugarcane.

The company also collaborated with will.i.am (musician) and launched EKOCYCLE- to promote recycling. It has a social mission-"make more sustainable living cool".

\section{6) Hindustan Unilever Limited}

HUL make a new Surf Excel Quick Wash which can save up to two buckets of water while washingclothes.

\section{7) Toyota}

It scores second spot in the Interbrand's Best Global Green Brands for 2014 but its fierce commitment to social involvement and green practices is still a priority. Toyota launched an initiative "Toyota ToghtherGreen" in collaboration with National Audubon Society. It also established a program called "Fellowship 
Program" to fund the conservation efforts by different leaders andcommunities.

\section{8) Nokia India}

Nokia has launched a recycling campaign for electronic waste.

\section{9) Ford}

Toyota lost its first spot to Ford for its green marketing initiatives. It uses $80 \%$ recycled material for its two very popular models i.e. Focus and Escape.

Another social initiative through Green Marketing is "The Living Roof". This is the largest one with an area of 10.4 acres which protects the building, insulate it and clean storm water.

\section{0) Reva Electric Car}

The company trying to build sustainable business is going for electric car market. With no use of petrol and diesel the company is saving natural resources and reducing pollution which is created by the normal vehicles.

\section{1) The Body Shop}

Making "Green” Fashionable (Rob Fenn). The Body Shop is one of the first companies that published a complete report on the CSR initiatives taken by the company. Almost 20 years back, the company established a fair trade program and it is the policy of the company of not testing their products on animals. This makes it more successful and created a loyal customer base (Rob Fenn).

12) Reckitt Benckiser Group Inc.
The company by launching Carbon 20 program is helping the customers to reduce their carbon footprints.

\section{3) Walt Disney}

Trains in Disneyland runs on biodiesel which is extracted from cooking oil which is used in their resort's hotels. They also make standards, for their employees to encourage them to reduce the environment impact while working, called "Green Standards". This benefitted them by a reduction of $10 \%$ in their use of electricity thereby giving them huge profits.

\section{4) Lifebuoy India}

Lifebuoy put up a free food stall in "khumbh Mela" with a tag on every bread, "Lifebuoy se hath dhoyakya?" with the aim to promote cleanliness. They have put up a liquid soap for consumers to wash hands first and then have free food. This proved to be very successful marketing strategy.

\section{CONCLUSION}

CSR is one of the factors responsible for the success of the company. It is among the duties of the company to be socially responsible. Companies have some duties towards the society and without fulfilling these duties, the company cannot survive. Environment management is one of the main variables of CSR. And Green Marketing is one way how companies can perform their environmental responsibility. By adopting Green Marketing as a social initiative, the companies are achieving two 
targets. One is- becoming socially and environmentally responsible company and second is all the benefits mentioned above in this paper. The example of the companies mentioned show that companies are involved in Strategic CSR. The companies know that by being environmentally and socially responsible, they can achieve much more than just a tag of 'A Socially Responsible Company'. This is the Strategic CSR whereby companies not just fulfil their social duty but reaping huge profits too. They have understood the importance of 'being green' as more and more consumers are now aware of the impact which companies have on their environment.

As mentioned in the paper, the consumers want to associate more with the companies that are green and active in CSR activities.

So, taking the advantage of the new preference of the consumers the companies have found a new way of earning profits by being socially active and hence, they are involved in 'Strategic CSR'.

\section{REFERENCES}

[1] It Pays To Be Green: Corporate Social Responsibility Meets the Bottom Line Nielsen Global Survey.

http://www.nielsen.com/us/en/insig hts/news/2014/it-pays- to-be-greencorporate-social-responsibilitymeets-the- bottom-line.html
[2] Corporate social responsibility: green marketing Written on 14 March 2008 Retrieved from: https://www.marketingmag. com.au/hubs-c/corporatesocial responsibilitygreen marketing/

[3] Taking a green initiative Rich Mintzer, feb 20, 2008. http://www.entrepreneur.com/article $/ 190572$

[4] Top 10 Green Marketing Campaigns Jennifer Kaplan http://ecopreneurist.com/2011/10/26 /top-10-green-marketingcampaigns/

[5] Corporations that went all out on 'green marketing' initiatives By Wendy Parish | February 24, 2015 http://www.marketingdive.com/news/ corporations-that-went-all-out-ongreen-marketing-initiatives/368032/

[6] http://www.ekocycle.com/about

[7] Using Community Involvement as Part of Your Green Marketing and CSR Strategy Sofia Ribeiro, 2010. http://greeneconomypost.com/com munity- involvement-greenmarketing-csr-8735.htm

[8] Are companies creating a CSR strategy for marketing or environmental reasons? Daria Boswell, Written on 29 Nov, 2012. http://www.quora.com/Arecompanies-creating-a-CSRstrategy-for-marketing-or- 
environmental-reasons

[9] Benefits of Corporate Social Responsibility Rob Fenn Retrieved from:

http://www.sustainablebusinesstool kit.com/benefits-of-corporatesocial-responsibility/

[10] Social responsibility in environmental marketing planning Jari Karna, Eric Hansen, Heikkijuslin European Journal of Marketing Vol. 37 No.5/6,2003 pp.848-871q MCB UP Limited 0309-0566.

DOI 10.1108/03090560310465170 http://educamarketing.unex.es/asig naturas/curso $\% 20$ doctorado/art $\% \mathrm{C}$ 3\%ADculos/environmental\%20 mk\%20planning_Karna $\% 20$ et $\% 20$ al.pdf

[11] What is CSR? United Nations Industrial Development organization http://www.unido.org/en/ whatwe-do/trade/csr/what-is-csr.html

[12] Green Marketing: Solving Dual Purpose of Marketing and Corporate Social Responsibility Salil Seth, M. S. Khan.

[13] Management Studies and Economic Systems (MSES), 1 (3), 181-188, winter 2015 C ZARSMIwww.msaes.org/pdf_758 8_800b3314d50a644e96a915a415 3a5155.html
[14] Green Marketing and Corporate Social Engagement as Strategy Tools -A Conceptual Framework André C. M. Menck and Dr. João Bento de Oliveira Filho International Journal of Humanities and Social Science, Vol. 4 No. 5; March 2014 Retrieved from: www.ijhssnet.com/journals/ Vol_4_No_5_March_2014/1.pdf 